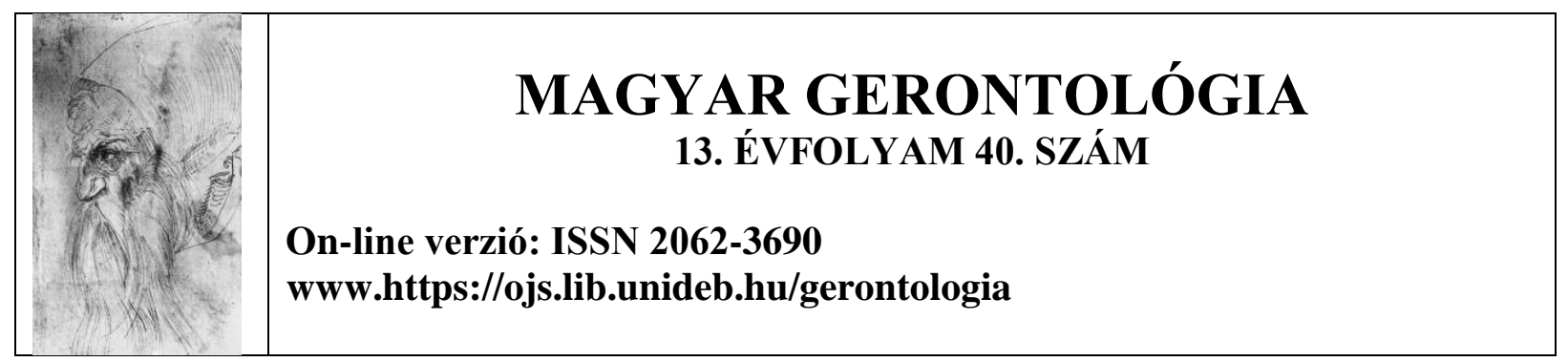

\title{
ÉSZLELT TÁRSAS TÁMASZ IDŐSKORBAN
}

\section{Ferwagner Anna, Dr. Pék Győző}

Debreceni Egyetem, Pszichológiai Intézet

Kulcsszavak: idősek, társas támasz, élettel való elégedettség, depresszió, idősödéssel kapcsolatos attitüdök

\begin{abstract}
Absztrakt
Háttér és célkitüzések: Kutatásunkban azt vizsgáltuk, hogy az észlelt társas támasz mértéke milyen tényezőktől függ (nem, életkor, családi állapot, egészség, önálló független életvitel feladása), hogyan függ össze az idősödés megélésével.

Módszer: Vizsgálatunkban a társas támaszt, az idősödéssel kapcsolatos attitűdöket, az élettel való elégedettséget, az időskori depressziót vizsgáló kérdőíveket alkalmaztunk.

Eredmények és következtetések: Az észlelt társas támasz az életkorral csökkenő tendenciát mutat, az egyedülállók, a rossz egészségi állapotban lévők és az idősotthonban élők esetében alacsonyabb. Mindhárom támasz fajta esetében elmondható, hogy míg az önálló független életvitelt folytatók esetében a korral csökken az észlelt társas támasz, addig az idősotthonban élők esetében a legfiatalabbaknál (65-74 év) a legalacsonyabb és a 75-89 év közöttiek esetében, illetve az instrumentális támasz a 90 év felettieknél a legmagasabb. Magasabb észlelt társas támasz esetén nagyobb mértékü az élettel való elégedettség, kisebb mértékü a depresszió és az idősödés megélése is pozitívabb. Fontos ugyanakkor megjegyezni, hogy a ténylegesen nyújtott támasz és az észlelt támasz nem azonos.
\end{abstract}




\title{
PERCEIVED SOCIAL SUPPORT IN OLD AGE
}

Keywords: elderly, old age, social support, life satisfaction, depression, attitudes to ageing

\begin{abstract}
Background and aims: In our research, we examined how the degree of perceived social support depends on factors (gender, age, marital status, health, giving up independent living) and how it is related to experiencing aging.

Methods: In our study, we used questionnaires examining social support, attitudes to ageing, life satisfaction, and depression in old age.

Results and discussion: Perceived social support shows a decreasing trend with age, and is lower in the case of singles, those in poor health, and those living in nursing homes. It can be said that all three types of support decreases with age at those living independent, but those living in nursing homes the social support is the lowest in the case of the youngest (65-74 years) and the highest at the of 75-89 years, and the instrumental support over 90 years old. Higher perceived social support results in higher levels of life satisfaction, lower level of depression and more positive experiences of ageing. It is important to note, however, that the support actually provided and the perceived support are not the same.
\end{abstract}

\section{Bevezetés}

Bár az elmúlt évtizedekben folyamatosan nőtt az élettartam, ez azonban nem feltétlenül jelent minőségi életéveket. Az életkor előrehaladtával romlásnak indul az általános egészségi állapot, csökken az aktivitás, a teherbíró képesség, csökken a mozgásterjedelem, akadályoztatottá válhat a mozgás, számos betegség jelenhet meg, mely hatással van az életminőségre is (Osváth, Árkovits és Csürke, 2014). Öregedő társadalmunkban az idősek arányának növekedése az idősellátás területén is egyre növekvő szükségleteket eredményez, egyre nagyobb igény mutatkozik az átmeneti vagy tartós segítségnyújtásra, támaszra.

Jelentős változások zajlanak a családi és baráti kapcsolatok terén is. A gyermekek családi otthonból elköltözése, az időskorban bekövetkező válás, a házastárs és az idővel egyre több közeli ismerős, barát halála mind az egyedüllét, az elmagányosodás irányába hat. Csökkenti ugyanakkor az elmagányosodás veszélyét az unokák születése és nevelésükbe bevonódás, illetve ha időskorára is családja körében tud élni az ember. 
Hazánkban a magánháztartásban élő 65 év felettiek kb. 29 \%-a egyedülálló (több, mint fél millió ember, föként nők), 40\%-a él a házastársával vagy élettársával, $23 \%$-a felnőtt gyermekével, illetve annak családjával, 8 \%-a pedig egyéb összetételü háztartásban (Székely, 2017). Egyre növekszik az elváltak aránya is, 2016-ban a 65 év feletti egyedülálló férfiak 27 \%-a, a nők 16 \%-a volt elvált, mely 8-10 \%-os növekedést jelent 1990-hez képest (Monostori és Gresits, 2018).

Az időskorban megromló egészségi állapotuk miatt az idősek egyre inkább szorulnak támaszra, ugyanakkor a közeli ismerősök elvesztésével erre egyre kevesebb a lehetőségük nyílik. Sok esetben pedig még maga az idős ember nyújt támaszt gyermekeinek, unokáinak. Az 55-69 év közötti korcsoport 61 \%-a szeretne saját otthonában maradva segítséget kapni, míg 5 \% tudja elképzelni a gyermekeivel való összeköltözést rászorultság esetén, további $31 \%$-uk pedig az idősotthonba költözést. (Monostori és Gresits, 2018)

A családok individualizációs folyamatai, az egyre gyakoribb válások, a munkahelyi leterheltség, a felgyorsult életvitel egyre kevésbé teszi lehetővé, hogy az idős családtagok családjuk körében tölthessék el utolsó éveiket, a családok jelentős része már nem tud olyan mértékü támaszt nyújtani az idős hozzátartozóiknak, amelyre szükségük lenne. Emiatt sokan döntenek idősotthonba költözés mellett, ahol megfelelö támaszt remélnek. Az időskor krízisei közt említhető a lakóhelyváltoztatást is, mely addigi otthonuk feladását jelenti. A magánlakásokban élő 65 év feletti idősek kb. $5 \%$-a tervezi idősotthonba költözést, ennek indokaként többségében lakásuk túl költséges fenntartását, illetve egészségi állapotuk megromlását említették (Székely, 2017).

A magánháztartásokban élő 65 éven felüli férfiak negyede, a nők több mint harmada számára jelent kisebb-nagyobb problémát az önellátás (tisztálkodás, öltözés, ágyból felkelés, háztartás ellátása), amely a kor előrehaladtával egyre súlyosbodik. Az önellátási nehézségekkel küszködők $55 \%$-a vesz igénybe segédeszközt, kér személyes segítséget, azonban az idősek több mint harmada szeretne nagyobb támogatásban részesülni. (Boros, 2017)

Az 1990-es évek óta folyamatosan növekvő tendenciát mutat az idősotthonokban és gondozóházakban ellátottak száma. Míg 1993-ban 30155 fő élt idősek otthonában, tíz évvel később már 44219 fő, 2016-ban 54239 fö, 2017-ben pedig már 54770 fő. Országszerte 910 db intézmény müködik, ezek közül $487 \mathrm{db}$ állami vagy önkormányzati fenntartású, $211 \mathrm{db}$ egyházi, továbbá 212 db civil (alapítvány, egyesület) vagy magán (gazdasági társaság, vállalkozás) fenntartású. Az intézményekben lévő férőhelyek száma 56288 fő elhelyezését teszi lehetővé, ebből az állami intézményekben 31680 fö, az egyházi intézményekben 13271 fö, a magán fenntartású intézményekben további 11337 fő elhelyezésére van lehetőség. Az 
ellátottak 57 \%-a állami (31 041 fó), 23 \%-a egyházi (12 522 fö), 20 \%-a (10 676 fö) magán fenntartású intézményben él. (Bácskay, 2017, 9.10-9.12. táblázatok alapján)A férőhelyek számát tekintve a 10-15 fős intézményektől a több száz fős intézményekig meglehetősen széles a kínálat. Az egyes intézmények felszereltsége, ellátottsága, programlehetőségei és térítési díjai is rendkívül eltérőek. Jellemzően 1-4 fős apartmanokban élnek az otthonok lakói. Mindez hozzájárulhat ahhoz, hogy bár nincs kitöltve a rendelkezésre álló kapacitás (56 288 férőhelyből csak 54239 betöltött), ugynakkor számos otthonban több éves (akár 10 éves is lehet) a várólista, továbbá a jelentős túljelentkezés miatt a bekerülés korhatárát egyes helyeken 65 évröl már 80 évre emelték. (Boga, 2015)

Az ellátottak $9 \%$-a (5 027 fö) 65 év alatti, 18 \%-a (9 870 fö) tartozik a 65-74 év közötti, $59 \%$-a (31 814 fö) a 75-89 év közötti és 14 \%-a (7 528 fö) a 90 év felettiek korcsoportjába. 74 éves kor alatt kiegyensúlyozott a férfiak és nők aránya, míg a 75-89 év közöttiek esetében négyszeres, a 90 év felettiek esetében hatszoros a nők száma a férfiakhoz képest. Kiemelkedő a 75-89 év közötti nők aránya, mely az összes ellátottnak a 47 \%-át (25 439 fó) adja. Összességében az otthonokban majd háromszor annyi nő él, mint férfi. Mindez a korábban már említett demográfiai trendeknek is betudható. (Bácskay, 2017, 9.13-9.14. táblázatok alapján)

Az idősek számára az életminőséget, s ezáltal az idősödés pozitív megélését az egészség megléte, a betegség és fájdalom hiánya mellett az emberi kapcsolatok minősége, a társas támasz megléte és a magányossággal szemben a családhoz tartozás is befolyásolja. (Lampek és Rétsági, 2015)

Időskorban a társas támogatás, a család, a barátok és a hivatásos segítők (pl. szociális gondozók) részéröl történő tényleges, illetve az idősek által észlelt segítségnyújtás szerepe felértékelődik, hiszen ekkor a barátok, hozzátartozók elhalálozásával eleve csökkennek a támaszforrások, ugyanakkor az idős emberek gyermekei, unokái maguk is támaszra szorulnak. Ez a társas támogatás lehet instrumentális támasz (pl. étkezésben, bevásárlásban nyújtott segítség), érzelmi-információs támasz (pl. meghallgatják, tanácsot adnak) vagy pozitív szociális interakciókon alapuló támasz (pl. akivel együtt lehet idejét eltöltheti, együtt tevékenykedhet).

A társas támasz a társas kapcsolatokban a törődés, gondoskodás, szeretet, megbecsülés, kölcsönösség, közösséghez tartozás megtapasztalását jelenti. A nehéz élethelyzetek, betegségek, átmeneti vagy tartós egészségkárosodás elviseléséhez, a betegségekből való felépülésben, a mentális és fizikai egészség megőrzésében, a krízishelyzetekkel való megküzdésben szintén rendkívül fontos a megfelelő társas támasz. (Forgács, 2015; Tiringer és Kaszás, 2013) 
A társas támasz által az egyén átélheti az érzelmi és fizikális biztonságot, valahova tartozást. Az erős családi kapcsolat jó előrejelzője az életminőségnek. A nehéz élethelyzetek, krízisek, betegségek, átmeneti vagy tartós egészségkárosodás elviseléséhez szintén rendkívül fontos a megfelelő társas támasz. (Kállai, 2007) A legnehezebb helyzetben azok vannak, akik időskorukra maradnak egyedül társuk elvesztését követően (Kopp és Székely, 2013). Egyedülállók esetében a társas támasz érzelmi, információs és szociális interakciókon alapuló dimenziója egyaránt kisebb, mint a házastársi vagy élettársi kapcsolatban élők esetében. (Sz. Makó és mtsai, 2016)

Kanadai önellátó idősek körében végzett felmérés eredménye szerint az alacsony szintü észlelt társas támasszal rendelkező idősek elégedetlenebbek az életükkel és inkább érzik magukat magányosnak. A 65-74 év közöttiek, a magasabb iskolai végzettséggel rendelkezők és a jobb anyagi helyzetben lévők inkább voltak elégedettek az életükkel és kevésbé érezték magukat magányosnak, mint az idősebbek, alacsonyabb végzettségüek és rosszabb anyagi helyzetben lévők. (Gilmour, 2012)

Unalan és mtsai. (2015) a saját otthonukban élő, 65 év feletti idősek esetében vizsgálta az időskori depresszió, a társas támasz és az időskori életminőség kapcsolatát. Az időskori életminőség vizsgálatára a WHO által kidolgozott WHOQOL-OLD skálát használták, amely a következő hat dimenzió, hat téma mentén méri fel az életminőséget: érzékelési képesség, autonómia, múltbeli-jelenbeli-jövőben tervezett tevékenységek, közösségben való részvétel, halál és haldoklás továbbá intimitás megélése. Kutatásuk eredménye alapján elmondható, hogy a depresszió és a társas támasz a WHOQOL-OLD skála mindegyik dimenziójával szignifikánsan korrelált. A depresszió jelenléte negatívan, míg a társas támasz megléte pozitívan befolyásolja az időskori életminőséget. A társas támasz különösen az érzékelési képesség, az autonómia, a múltbeli-jelenbeli-jövőben tervezett tevékenységek és az intimitás dimenziók kapcsán jelent meg protektív faktorként.

Kai-Kuen Leung és mtsai (2007) vizsgálatukban úgy találták, hogy az idősek mentális egészségét a társas támasz befolyásolja, az érzelmi támasz fontosabbnak bizonyult az instrumentális támasznál a mentális egészség kapcsán, illetve fontos tényező volt a családi szerepvállalás. Kisebb mértékü érzelmi támogatás nagyobb mértékü szorongással és depresszióval járt, illetve a nők több szorongásos tünetet mutattak, mint a férfiak.

Ibrahim és mtsai (2013) vizsgálatukban szintén az érzelmi-információs támasz fontosságát találták, eredményeik alapján az egyes támasz típusok közül az érzelmi-információs támasz korrelál leginkább az egészségi állapottal. 
Különösen veszélyeztetett csoportnak számít a minél idősebb nők csoportja, mivel a nők a férfiaknál hosszabb ideig élnek ugyan, azonban az egészségben várható élettartamuk nem különbözik jelentősen a férfiakétól, így összességében a nők hosszabb betegségben töltött időszakra számíthatnak életük végén, rendszerint özvegy, elvált vagy egyedülálló státuszban, többnyire férfitársaiknál kisebb összegű nyugdíjjal. (Monostori és Gresits, 2018; Pék, 2007)

Időskorban a depressziót leginkább a kiszolgáltatottság, embertelen bánásmód, lakáskörülmények, gyógyszerellátás, közbiztonság, kikapcsolódás hiánya, célok hiánya és a magány váltja ki (Lampek és Rétsági, 2015). Morley (2010) idősotthonokban végzett felmérése alapján az otthonokban élők 48 \%-a érintett volt kisebb vagy nagyobb fokú depresszióval. Jongenelis és mts. (2004), valamint Choi, Ransom, és Wyllie (2008) idősotthonokban a depresszió rizikótényezői, okai közt említik a függetlenség, szabadság elvesztését, a magányosság érzését, az autonómia elvesztését, a nem megfelelő mennyiségű és minőségü személyzetet és szolgáltatást (pl. tevékenységek hiánya), a társas támasz hiányát, a mozgás- és látáskorlátozottságot.

A társas támasz, a szociális háló hiánya növeli az elmagányosodás veszélyét, kikapcsolódás lehetőségének hiányát, amik a depresszió kiváltói. Az alacsony szintű észlelt társas támasszal rendelkező idősek elégedetlenebbek az életükkel és inkább érzik magukat magányosnak. Időskorban a meggyengült egészség miatt a társas támasz szerepe felértékelődik, ugyanakkor épp időskorra csökken jelentősen a támogatást nyújtók száma (a családtagok, egykori barátok halálával), sokszor magukra maradnak az idősek.

Kutatásunkban azt vizsgáltuk, hogy az észlelt társas támasz mértéke milyen tényezőktől függ (pl. életkor, családi állapot, egészség), hogyan függ össze az idősödés megélésével, milyen eltérés figyelhető meg az idősödés megélésében a különböző élethelyzetben lévő (önálló független életvitel feladása szempontjából intézményesített vagy önálló független életvitelt folytatók), illetve a különböző korcsoportba tartozó 65 évnél idősebb emberek között. Az egyes korcsoportok a WHO besorolás szerint kerültek kialakításra: 65-74 év közöttiek (idősödők), 75-89 év közöttiek (időskorúak), 90 év felettiek (aggastyánok). (Lampek és Rétsági, 2015) Az idősödés megélésének megitélésére az idősödéssel kapcsolatos attitüdök, az élettel való elégedettség és az időskori depresszió dimenziókat használtuk. 


\section{Módszerek és minta}

Vizsgálatunkat 2018-2019-ben végeztük, a kutatás etikai engedélyét a Debreceni Egyetem 2018/110. számon adta meg. A vizsgálati személyek 65. életévüket betöltött személyek voltak, toborzásuk részben informális kapcsolati hálón keresztül, részben idősotthonok és idősklubok megkeresésével történt. A speciális korosztály vizsgálata nyomtatott kérdőív használatát tette szükségessé, az idősebbeknek szükséges volt a teljes kérdőív felolvasása is. A vizsgálatot nehezítette, hogy az intézményesített életvitelt folytatók esetében az idősotthonokban meglehetősen alacsony a 65-74 év közötti korosztály jelenléte, míg az önálló független életvitelt folytatók körében ezen korcsoport érhető el a legkönnyebben és a legnagyobb számban, ugyanakkor a 90 év felettiek tekintetében fordított a helyzet. A vizsgálatot tovább nehezítette az alacsony részvételi hajlandóság. Az intézményesített életvitelt folytatók csoportjának tagjai végül a Fővárosi Önkormányzat Kamaraerdei Idősek Otthona, a Katolikus Szeretetszolgálat XXIII. János Otthon - Okos Gizella Ház, a pátyi Levendula Ház és a budaörsi „Élet-Hossz” Idősek Otthona lakói közül kerültek ki.

A mintavétel során a nemek közötti egyenletes megoszlás nem volt biztosítható, mivel az idősotthonokban többségében nők éltek. Arra azonban törekedtünk, hogy az önálló független életvitelt folytatók és az intézményesített életvitelt folytatók csoportjában hasonló legyen a nemek megoszlása. A vizsgálatban 110 fö vett részt, a minta szociodemográfiai megoszlását az 1. táblázat tartalmazza:

\begin{tabular}{|c|c|c|}
\hline & fö & $\%$ \\
\hline \multicolumn{3}{|l|}{ Nem: } \\
\hline - férfi & 24 & 21,8 \\
\hline • nő & 86 & 78,2 \\
\hline \multicolumn{3}{|l|}{ Életkor: } \\
\hline - idősödő (65-74 év) & 37 & 33,6 \\
\hline - időskorú (75-89 év) & 57 & 48,2 \\
\hline - $\quad$ aggastyán (90 év felett) & 20 & 18,2 \\
\hline \multicolumn{3}{|l|}{ Legmagasabb iskolai végzettség: } \\
\hline - általános iskola & 15 & 13,6 \\
\hline - középiskola & 47 & 42,8 \\
\hline - föiskola, egyetem vagy $\mathrm{PhD}$ & 48 & 43,6 \\
\hline
\end{tabular}




\begin{tabular}{|c|c|c|}
\hline Családi állapot: & & \\
\hline - egydülálló & 6 & 5,5 \\
\hline - $\quad$ elvált & 10 & 9,1 \\
\hline • özvegy & 59 & 53,6 \\
\hline - házas vagy élettárs & 35 & 31,8 \\
\hline Lakhely: & & \\
\hline • föváros & 87 & 79,1 \\
\hline - $\quad$ vidék & 23 & 20,9 \\
\hline Önellátás: & & \\
\hline - önálló független életvitelüek & 55 & 50,0 \\
\hline $\begin{array}{ll}\text { - } & \text { intézményesített életvitelűek } \\
\text { (idősotthonban élők) } & \end{array}$ & 55 & 50,0 \\
\hline
\end{tabular}

1. táblázat: A vizsgálati minta megoszlása nem, életkor, családi állapot, legmagasabb iskolai végzettség, lakóhely és az önálló független életvitel feladása szerint

A vizsgálat során saját szerkesztésü kérdőivet (alapvető demográfiai adatok), továbbá az alábbi standardizált kérdőíveket használtuk.

Társas Támasz Kérdöív (MOS SSS, Medical Outcomes Study Social Support Survey, magyar nyelvü validáció: Sz. Makó és mtsai., 2016)

A kérdőív 20 itemet tartalmaz. Az első item a szoros baráti és családi kapcsolatok számát méri fel, a többi item a támogatottságot vizsgálja, egy 5-fokozatú Likert-skálán kell eldönteni, hogy az adott támaszfajta milyen gyakran áll rendelkezésre szükség esetén, minél nagyobb a pontszám, annál nagyobb az észlelt társas támasz mértéke. A kérdőív hazai adaptációja során három alskálát sikerült elkülöníteni: érzelmi-információs támasz (8 item, pl. „, akire számithat, hogy meghallgatja Önt, ha ki akarja önteni a szívét”), pozitív szociális interakciókon alapuló támasz (7 item, pl. ,, akivel jó együtt lenni”), instrumentális támasz (4 item, pl. „aki segit, ha ágynak esik”). A kérdőív megbízhatósága magas (Cronbach-alfa az érzelmi-információs támasz alskála esetében 0.94 , a pozitív szociális interakciókon alapuló tármasz esetében 0.92, míg az instrumentális támasz esetében 0.89). 
Idősödéssel Kapcsolatos Attitüdök Kérdöív (AAQ, Attitudes to Ageing Questionnaire, magyar nyelvü validáció: Tróznai és Kullmann, 2007)

Az idősödéssel kapcsolatos attitűdök mérésére kidolgozott kérdőív 24 itemből áll, egy 5-fokú Likert-skálán szükséges megadni, hogy a válaszadó mennyire ért egyet az egyes itemekben megfogalmazott állításokkal. Az állítások három alskálán (8-8 item) oszlanak meg: pszichológiai növekedés, fizikai változás, pszichoszociális veszteség. A pszichológiai növekedés alskála az egész életen át tartó fejlődés lehetőségét fogalmazza meg, az élet pozitívumaira kérdez rá (pl. ,, Ahogy öregszünk, jobban tudjuk megoldani az élet nehézségeit”). A fizikai változás alskála az időskorban bekövetkező testi müködésre, annak változásaira kérdez rá (pl. „,Testgyakorlással olyan aktívan tartom magam, ahogy lehetséges”). A pszichoszociális veszteség alskála a pszichés és szociális veszteségeket foglalja magában, az idősödésre, mint negatív élményre kérdez rá (pl. „,Az időskor a magányosság időszaka

Élettel való Elégedettség Skála (SWLS, Satisfaction With Life Scale, magyar nyelvü validáció: Martos és mts., 2014)

Az élettel való elégedettség egy adott személy életminőségének szubjektív kognitív értékelése, a pozitív életminőség, a lelki egészség, szubjektív jóllét egyik összetevője. A szubjektív jóllét feltárását célozó teszt egy 5 itemből álló kérdőív, a kérdésekkel való egyetértés 7 fokozatú Likert-skálán fejezhető ki (pl. „,Meg vagyok elégedve az életemmel”). A pontszámok összegzése által kapott érték fejezi ki az elégedettséget. Értékelés: rendkívül elégedett (31-35), elégedett (26-30), enyhén elégedett (21-25), neutrális (20), enyhén elégedetlen (15-19), elégedetlen (10-14), rendkívül elégedetlen (5-9). Magyar nyelvü adaptációjának megbízhatóságát magasnak értékelték (Cronbach-alfa 0,84 felett).

Időskori Depresszió Skála rövidített változat (GDS, Geriatric Depression Scale, magyar nyelvü validáció: 75 papír-ceruza teszt)

Az időskori depresszió kiszürésére használatos tesz, melynek eredeti változata 31 , rövidített változata 15 , a napi életmódra és érzésekre vonatkozó kérdést tartalmaz. A rövidített változatban minden ,,igen” válasz 1 pontot ér a 2., 3., 4., 6., 8., 9., 10., 12., 14., 15. itemek esetében és minden „nem” válasz szintén 1 pontot ér az 1., 5., 7., 11., 13. itemek esetében. Értékelés: normál (0-4), enyhe depresszió (5-8), mérsékelt depresszió (9-11), súlyos depresszió (12-15). 
Vizsgálatunkban a következő hipotéziseket fogalmaztuk meg. H1: Az észlelt társas támasz mértéke eltérő az egyes korcsoportokban, az életkor előrehaladtával csökken a társas támasz. H2: Az észlelt társas támasz mértéke eltérő a különböző élethelyzetekben, az intézményesített életvitelt folytatók nagyobb mértékű támaszra számíthatnak, mint az önálló független életvitelt folytató idősek. $H 3$ : Az életkor és az élethelyzet együttesen hatással van az észlelt társas támasz mértékére.

A felvett kérdőívek eredményeit Microsoft Excel és RStudio matematikai-statisztikai programmal elemeztük. A saját szerkesztésü kérdőív diszkrét változóinak (nem, korcsoport, családi állapot, önálló független életvitel feladása, egészségi állapot) eloszlás vizsgálata történt annak megállapítása érdekében, mely csoportok összevetésére alkalmas a minta. Valamennyi folytonos változóra (társas támasz alskálái) kapott pontszámok, továbbá értékek esetében normalitás vizsgálatot végeztünk a Shapiro-Wilk teszttel ( $p>0.05$ esetén a változó normál eloszlású). Mivel az egyes csoportokban a változók eloszlása vegyesen normális és nem normális eloszlást, de többségében nem normális eloszlást mutatott, így a változók összehasonlítására az egyes csoportokban egységesen lineáris modellt, Mann-Whitney próbát, illetve Kruskal-Wallis-próbát alkalmaztuk és a medián értékek kerültek megadásra. A folytonos változók közti összefüggés vizsgálata Spearman-féle rangkorrelációval történt.

\section{Eredmények}

Támogató személyek száma:

A Társas Támasz Kérdőív első kérdése a támogatók számára kérdez rá: „Körülbelül hány közeli barátja és rokona van (olyan emberek, akikkel nem feszélyezi magát, és bármiröl tud beszélgetni, ami az eszébe jut)?"

Az eredmények alapján szignifikáns különbség van a nemek között, az látszik, hogy nők csak fele annyi támogatót észlelnek maguk körül, mint a férfiak ( $\mathrm{p}=0.02524$; medián férfiak=10,0; medián nők=5,0). Szintén szignifikáns különbség van az önálló független életvitel feladásában, az intézményesített életvitelt folytatók kevesebb támogató személyt észlelnek maguk körül ( $\mathrm{p}=6.989 \mathrm{e}-3$; medián intézményesített=5,0; medián önálló=6,0). Az egyes korcsoportok kapcsán elmondható, hogy az életkor előrehaladtával csökken a támogatók száma, egyre kevesebb a segítő (pl. házastárs, családtagok, barátok) az idősek mellett ( $p=0.1488$; medián idősödők=6,0; medián időskorúak=6,0; medián aggastyánok=4,5), illetve a 
különböző egészségi állapotban lévők közül a rossz és közepes egészségi állapotban lévők kevesebb támogatóról számoltak be, mint a jó egészségnek örvendők ( $\mathrm{p}=0.1447$; medián rossz, kielégítő=5,0; medián közepes=5,0; medián jó, kiváló=7,5). Családi állapot kapcsán pedig elmondható, hogy a válaszadók közül az egyedülállók számoltak be a legkevesebb támogatóról, szemben a házasságban vagy élettársi kapcsolatban élőkkel ( $\mathrm{p}=0.0788$; medián elváltak=5,0; medián egyedülállók=2,5; medián özvegyek=6,0; medián házasok=7,0).

Az önálló független életvitel feladása és az életkor változók együttes hatásának vizsgálatakor a lineáris modell árnyaltabb képet mutatott $\left(\mathrm{p}=5.078 \mathrm{e}-3 ; \mathrm{R}^{2}=0.1465 ; \mathrm{F}(5\right.$, 104)=3.571). A 2. táblázatban látható eredmények alapján jól látszik, hogy az önálló független életvitelt folytatók és az intézményesített életvitelt folytatók közt a legfiatalabb korosztály (6574 év közöttiek) esetében a legnagyobb a különbség, majd ez a különbség a 90 év felettiek korcsoportjában kiegyenlítődik. Legkevesebb támogatóról az intézményesített életvitelt folytatók közül a legfiatalabb korosztály számolt be. Ök azok, akik fiatalon, túl korán, hirtelen jött betegség, baleset vagy elhúzódó felépülés miatt kerültek olyan állapotba, amely önálló független életvitelük feladásához vezetett. Ezzel a helyzettel megbirkózni rendkívül nehéz, esetükben volt legmagasabb a depresszió mértéke is. Jól látszik a támogatók számából, hogy az idősek az átlagosan 2 gyermekük, esetleg 2-3 unokájuk mellett több támogatót jelöltek, tehát a többi családtag, barátok, hivatásos segítők szerepe jelentős lehet.

\begin{tabular}{|l|l|c|c|c|}
\hline \multicolumn{2}{|c|}{} & \multicolumn{3}{|c|}{ Életkor } \\
\cline { 2 - 5 } & $\mathbf{6 5 - 7 4}$ év & $\mathbf{7 5 - 8 9}$ év & 90 év felett \\
\hline \multirow{2}{*}{$\begin{array}{l}\text { Önálló független } \\
\text { életvitel feladása }\end{array}$} & \begin{tabular}{l} 
életvitelt folytatók \\
\cline { 2 - 5 }
\end{tabular} & 10 & 8,5 & $\underline{4^{*}}$ \\
\cline { 2 - 5 } & $\begin{array}{l}\text { Intézményesített } \\
\text { életvitelt folytatók }\end{array}$ & $\underline{3,5^{*}}$ & 5 & 5 \\
\hline
\end{tabular}

2. táblázat: Támogató személyek száma (fö) az egyes korcsoportokban az önálló független életvitelt folytatók és az intézményesitett életvitelt folytatók közt a Társas Támasz Kérdöív elsö kérdésére adott válasz alapján (lineáris modell; medián értékek)

Instrumentális támasz:

Instrumentális támasz tekintetében nincs szignifikáns különbség a nemek $(\mathrm{p}=0.5995$; medián férfi $=4,75$; medián nő $=4,75)$, a korcsoportok $(\mathrm{p}=0.7228$; medián idősödők $=4,75$; 
medián időskorúak=4,75; medián aggastyánok=4,625) és a különböző egészségi állapotban lévők ( $\mathrm{p}=0.1552$; medián rossz, kielégítő=4,5; medián közepes $=4,75$; jó, kiváló $=5,0$ ) között. Önálló független életvitel feladása kapcsán az önálló független életvitelt folytatók kicsivel nagyobb instrumentális támaszról számoltak be $(\mathrm{p}=2,463 \mathrm{e}-3$; medián intézményesített=4,5; medián önálló=5,0). Családi állapot kapcsán pedig elmondható, hogy a válaszadók közül az elváltak tapasztalták a legkisebb, míg a házasok a legnagyobb mértékü instrumentális támaszt ( $\mathrm{p}=0.02219$; medián elváltak=4,0; medián egyedülállók=4,5; medián özvegyek=4,75; medián házasok=5,0).

Az önálló független életvitel feladása és az életkor változók együttes hatásának vizsgálatakor a lineáris modell már árnyaltabb képet mutatott $\left(\mathrm{p}=7.371 \mathrm{e}-5 ; \mathrm{R}^{2}=0.2217 ; \mathrm{F}(5\right.$, 104)=5.924). A 3. táblázatban látható eredmények alapján jól látszik, hogy az intézményesített életvitelt folytatók esetében ugyanis az életkorral nem csökken, hanem szignifikánsan nő az észlelt instrumentális támasz. Az intézményesített életvitelt folytatók közül a legidősebb emberek tehát úgy érzik, megkapják a szükséges fizikális segítséget. A legkisebb mértékü támaszról, ahogy a támogatók számánál láttuk, itt is az intézményesített életvitelt folytatók közül a legfiatalabb korosztály (65-74 év közötti) számolt be. Ők érzékelhetik úgy, hogy rendkívül megromlott egészségi állapotuk még több fizikális törődést igényelne.

\begin{tabular}{|l|l|c|c|c|}
\hline \multicolumn{2}{|c|}{} & \multicolumn{3}{c|}{ Életkor } \\
\cline { 3 - 5 } & $\begin{array}{l}\text { Önálló független } \\
\text { életvitelt folytatók }\end{array}$ & 5,0 & 5,0 & 4,25 \\
\hline \multirow{2}{*}{$\begin{array}{l}\text { Önálló független } \\
\text { életvitel feladása }\end{array}$} & $\begin{array}{l}\text { Intézményesített } \\
\text { életvitelt folytatók }\end{array}$ & $\underline{3,875^{*}}$ & 4,5 & 4,75 \\
\cline { 2 - 5 } & & 90 év felett \\
\hline
\end{tabular}

3. táblázat: Észlelt instrumentális támasz mértéke az egyes korcsoportokban az önálló független életvitelt folytatók és az intézményesitett életvitelt folytatók közt a Társas Támasz Kérdöiv 2-20. kérdéseire adott válasz alapján (lineáris modell; medián értékek)

Érzelmi információs támasz:

Érzelmi-információs támasz tekintetében nincs szignifikáns különbség a nemek ( $\mathrm{p}=0.856$; medián férfi=4,25; medián nő=4,125) között, ugyanakkor szignifikáns különbség van a korcsoportok, a különböző egészségi állapotban lévők és a különböző családi állapotúak 
között, továbbá az önálló független életvitel feladása szempontjából. Az egyes korcsoportok közül a legidősebbek észlelik a legkisebb érzelmi-információs támaszt ( $\mathrm{p}=0.02292$; medián idősödők=4,375; medián időskorúak=4,25; medián aggastyánok=3,375), a különböző egészségi állapotban lévők közül a rossz egészségi állapotban lévők ( $\mathrm{p}=2.136 \mathrm{e}-5$; medián rossz, kielégítő $=3,75$; medián közepes $=4,0$; medián jó, kiváló=4,875), a különböző családi állapotúak közül az egyedülállók ( $\mathrm{p}=1.267 \mathrm{e}-3$; medián elváltak=4,375; medián egyedülállók=3,5; medián özvegyek=3,75; medián házasok=4,625), míg önálló független életvitel feladása szempontjából az intézményesített életvitelt folytatók ( $\mathrm{p}=4.618 \mathrm{e}-5$; medián intézményesített $=3,75$; medián önálló=4,5) észlelik a legkisebb érzelmi-információs támaszt.

$\mathrm{Az}$ önálló független életvitel feladása és az életkor változók együttes hatásának vizsgálatakor a lineáris modell még árnyaltabb képet mutatott $\left(\mathrm{p}=2.936 \mathrm{e}-6 ; \mathrm{R}^{2}=0.2725 ; \mathrm{F}(5\right.$, 104)=7.79). A 4. táblázatban látható eredmények alapján jól látszik, hogy míg az önálló független életvitelt folytatók esetében a korral csökken az érzelmi-információs támasz, addig az intézményesített életvitelt folytatók esetében a legfiatalabbaknál (65-74 év) a legalacsonyabb és a 75-89 év közöttiek esetében a legmagasabb, ugyanakkor minden korcsoportban az intézményesített életvitelt folytatók körében alacsonyabb az észlelt érzelmi-interakciós támasz, mint az önálló független életvitelt folytatók körében. A legkisebb mértékủ támaszról, ahogy az instrumentális támasznál is láttuk, itt is az intézményesített életvitelt folytató legfiatalabb korosztály (65-74 év közötti) számolt be. Ök érzékelhetik úgy, hogy rendkívül megromlott egészségi állapotuk miatt több érzelmi törődésre lenne szükségük.

\begin{tabular}{|l|l|c|c|c|}
\hline \multicolumn{2}{|c|}{} & \multicolumn{3}{c|}{ Életkor } \\
\cline { 3 - 5 } & Önálló független & $\mathbf{6 5 - 7 4}$ év & $\mathbf{7 5 - 8 9}$ év & 90 év felett \\
\hline \multirow{2}{*}{$\begin{array}{l}\text { Önálló független } \\
\text { életvitel feladása }\end{array}$} & \begin{tabular}{l} 
életvitelt folytatók \\
\cline { 2 - 5 }
\end{tabular} & 4,75 & 4,438 & 3,688 \\
& $\begin{array}{l}\text { Intézményesített } \\
\text { életvitelt folytatók }\end{array}$ & $\underline{3,0^{*}}$ & 3,875 & 3,062 \\
\hline
\end{tabular}

4. táblázat: Észlelt érzelmi-információs támasz mértéke az egyes korcsoportokban az önálló független életvitelt folytatók és az intézményesitett életvitelt folytatók közt a Társas Támasz Kérdőiv 2-20. kérdéseire adott válasz alapján (lineáris modell; medián értékek) 
Pozitív szociális interakciókon alapuló támasz:

Pozitív szociális interakciókon alapuló támasz tekintetében nincs szignifikáns különbség a nemek ( $\mathrm{p}=0.6235$; medián férfi $=4,5$; medián nő=4,143) között, ugyanakkor szignifikáns különbség van a korcsoportok, a különböző egészségi állapotban lévők és a különböző családi állapotúak között, továbbá az önálló független életvitel feladása szempontjából. Az egyes korcsoportok közül a legidősebbek észlelik a legkisebb mértékü pozitív szociális interakciókon alapuló támaszt ( $\mathrm{p}=3.871 \mathrm{e}-3$; medián idősödők=4,571; medián időskorúak=4,143; medián aggastyánok=3,571), a különböző egészségi állapotban lévők közül a rossz egészségi állapotban lévők ( $\mathrm{p}=4.396 \mathrm{e}-5$; medián rossz, kielégitő $=3,714$; medián közepes=4,143; medián jó, kiváló=5,0), a különbözö családi állapotúak közül az egyedülállók ( $\mathrm{p}=4.652 \mathrm{e}-5$; medián elváltak=4,0; medián egyedülállók $=3,5$; medián özvegyek=3,857; medián házasok=5,0), míg önálló független életvitel feladása szempontjából az intézményesített életvitelt folytatók ( $\mathrm{p}=8.65 \mathrm{e}-5$; medián intézményesített=3,714; medián önálló=4,714) észlelik a legkisebb mértékủ pozitív szociális interakciókon alapuló támaszt.

$\mathrm{Az}$ önálló független életvitel feladása és az életkor változók együttes hatásának vizsgálatakor a lineáris modell még árnyaltabb képet mutatott $\left(\mathrm{p}=9.673 \mathrm{e}-7 ; \mathrm{R}^{2}=0.289 ; \mathrm{F}(5\right.$, 104)=8.453). Az 5. táblázatban látható eredmények alapján jól látszik, hogy míg az önálló független életvitelt folytatók esetében a korral csökken a pozitív szociális interakciókon alapuló támasz, addig az intézményesített életvitelt folytatók esetében a legfiatalabbaknál (65-74 év) a legalacsonyabb és a 75-89 év közöttiek esetében a legmagasabb, ugyanakkor minden korcsoportban az intézményesített életvitelt folytatók körében alacsonyabb a pozitív szociális interakciókon alapuló támasz, mint az önálló független életvitelt folytatók körében. A legkisebb mértékü támaszról, ahogy az érzelmi-információs támasznál is láttuk, itt is az intézményesített életvitelt folytató legfiatalabb korosztály (65-74 év közötti) számolt be. Ök érzékelhetik úgy, hogy rendkívül megromlott egészségi állapotuk miatt kevesebb szociális interakcióban lehet részük és a meglévőnél többet igényelnek. 


\begin{tabular}{|l|l|c|c|c|}
\hline \multicolumn{2}{|c|}{} & \multicolumn{3}{|c|}{ Életkor } \\
\cline { 3 - 5 } & $\begin{array}{l}\text { Önálló független } \\
\text { életvitelt folytatók }\end{array}$ & 5,0 & 4,714 & 3,714 \\
\hline \multirow{2}{*}{$\begin{array}{l}\text { Önálló független } \\
\text { életvitel feladása }\end{array}$} & $\begin{array}{l}\text { Intézményesített } \\
\text { életvitelt folytatók }\end{array}$ & $\underline{3,357^{*}}$ & 3,857 & 3,5 \\
\hline
\end{tabular}

5. táblázat: Észlelt pozitív szociális interakciókon alapuló támasz mértéke az egyes korcsoportokban az önálló független életvitelt folytatók és az intézményesitett életvitelt folytatók közt a Társas Támasz Kérdöív 2-20. kérdéseire adott válasz alapján (lineáris modell; medián értékek)

Támasz típusok összehasonlítása

Egyik támasztípus sem különbözik szignifikánsan a férfiak és a nők esetében, továbbá mindkét nem esetében az érzelmi-információs támasz bizonyult a legkisebb, míg az instrumentális támasz a legnagyobb mértékünek, amely az 1. ábrán látható.

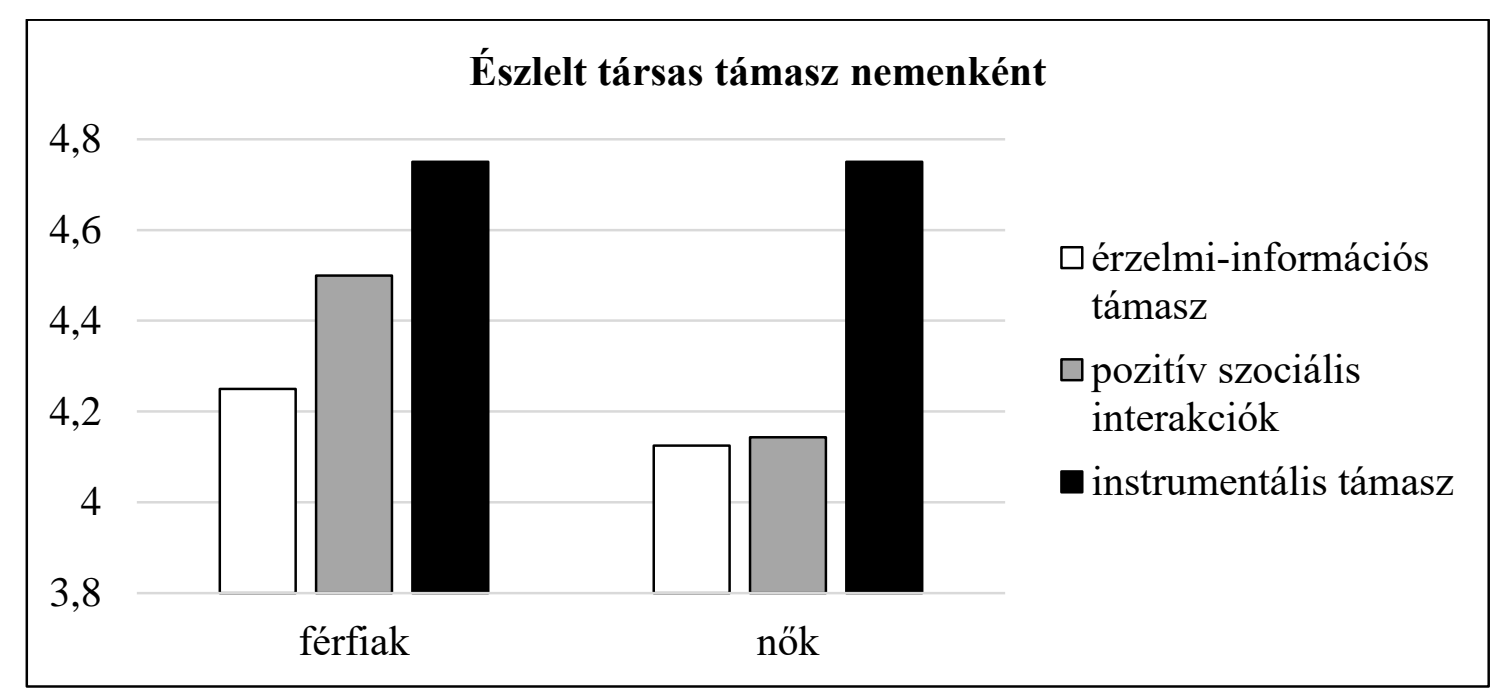

1. ábra: Észlelt társas támasz típusok összehasonlitása nemenként (férfiak; nök) a Társas Támasz Kérdöív 2-20. kérdéseire adott válasz alapján (lineáris modell; medián értékek)

A rossz és kielégítő egészségi állapotban lévők szignifikánsan kisebb támaszt észleltek az instrumentális támaszon kívüli támasztípusok esetében, mint a jó és kiváló egészségi állapotban 
lévők, továbbá minden esetben az érzelmi-információs támasz bizonyult a legkisebb, míg az instrumentális támasz a legnagyobb mértékünek, amely a 2. ábrán látható.

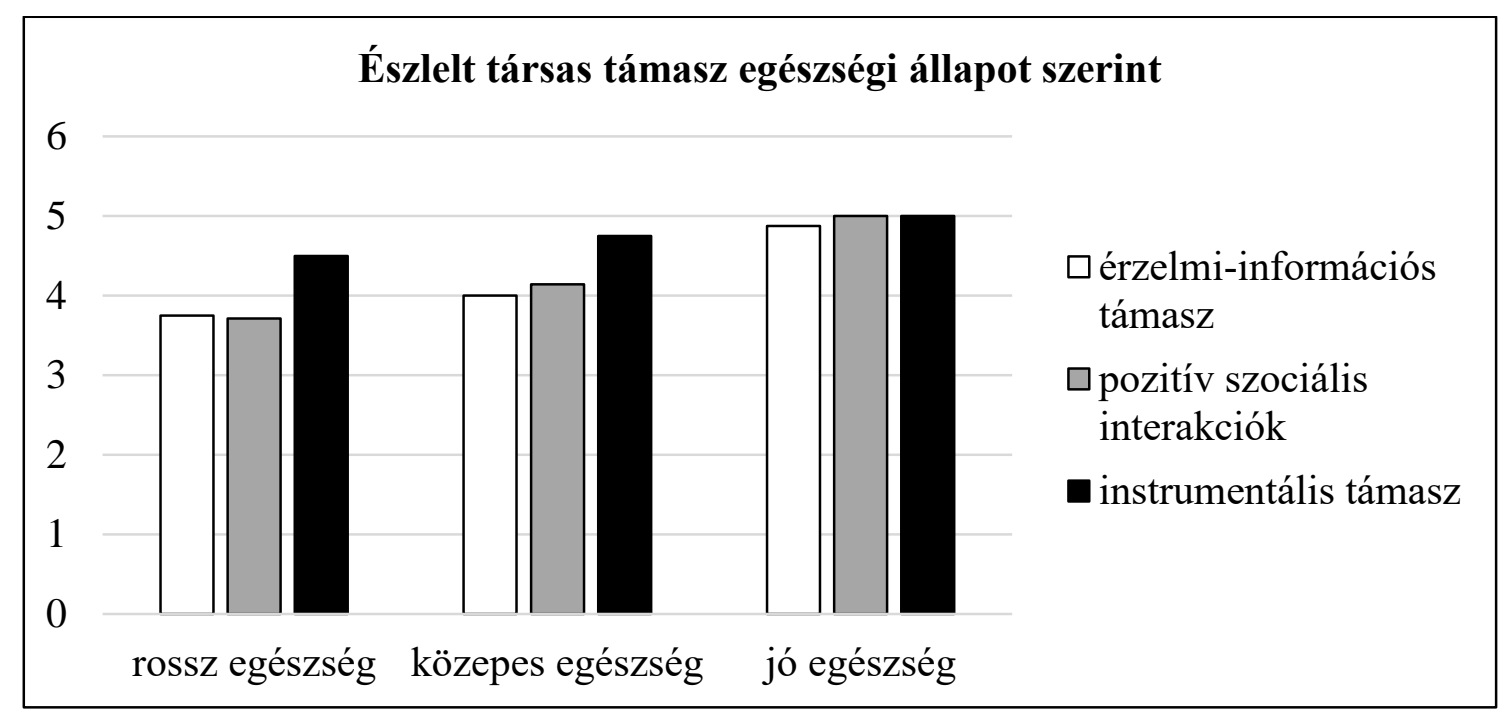

2. ábra: Észlelt társas támasz típusok összehasonlítása egészségi állapotok szerint (rosszkielégítö egészségi állapot; közepes egészségi állapot; jó-kiváló egészségi állapot) a Társas Támasz Kérdöív 2-20. kérdéseire adott válasz alapján (lineáris modell; medián értékek)

Az egyedülállók és elváltak szignifikánsan kisebb támaszról számoltak be, mint a házasságban vagy élettársi kapcsolatban élők, továbbá az elváltak kivételével minden esetben az érzelmiinformációs támasz bizonyult a legkisebb, míg az instrumentális támasz a legnagyobb mértékünek, amely a 3. ábrán látható. 


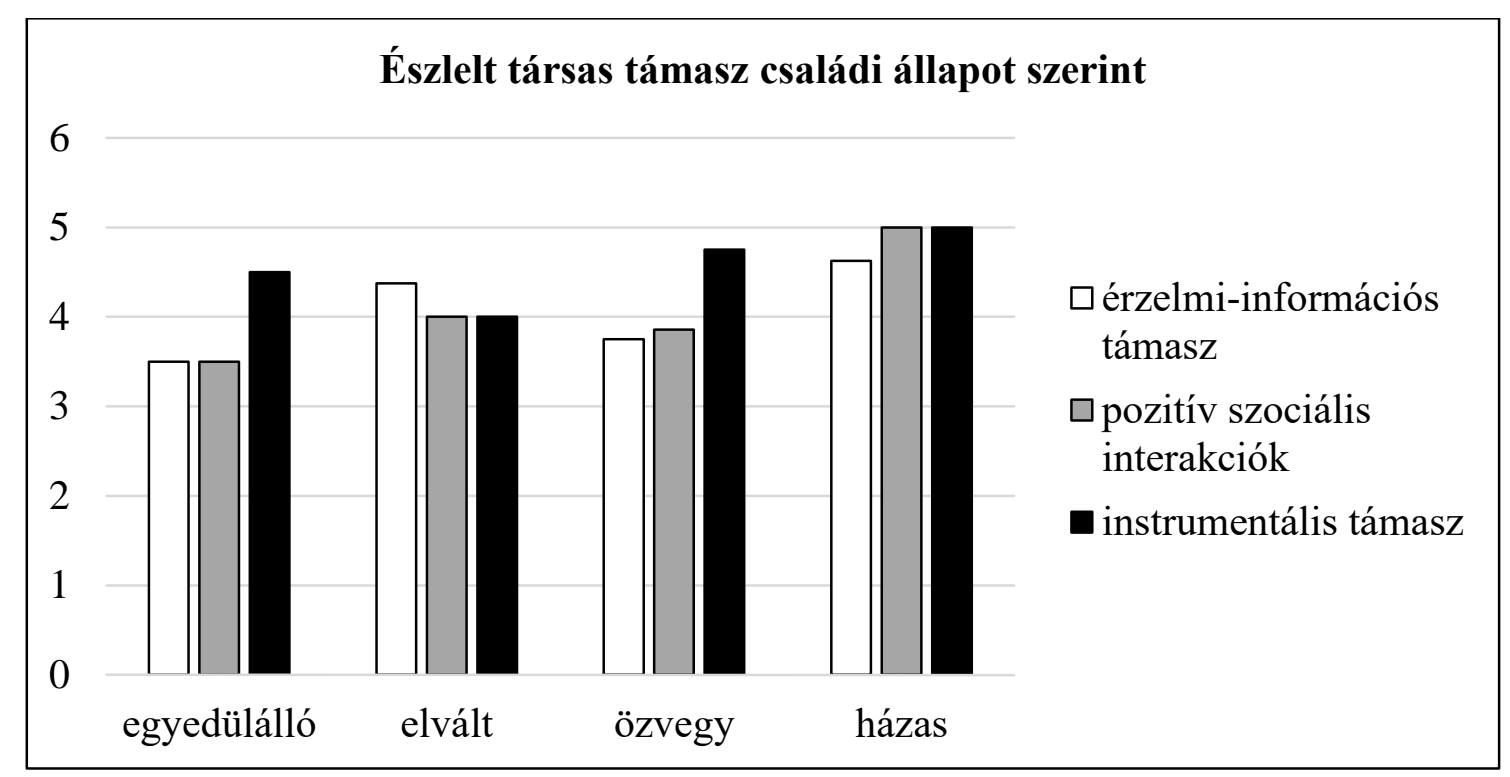

3. ábra: Észlelt társas támasz típusok összehasonlitása családi állapot szerint (egyedülállók; elváltak; özvegyek; házasságban vagy élettársi kapcsolatban élök) a Társas Támasz Kérdöív 2-20. kérdéseire adott válasz alapján (lineáris modell; medián értékek)

Az életkorral csökkenő tendencia figyelhető meg mindegyik támasz típus esetében, továbbá minden korcsoportban az érzelmi-információs támasz kisebb mértékünek bizonyult, mint az instrumentális támasz, amely a 4. ábrán látható.

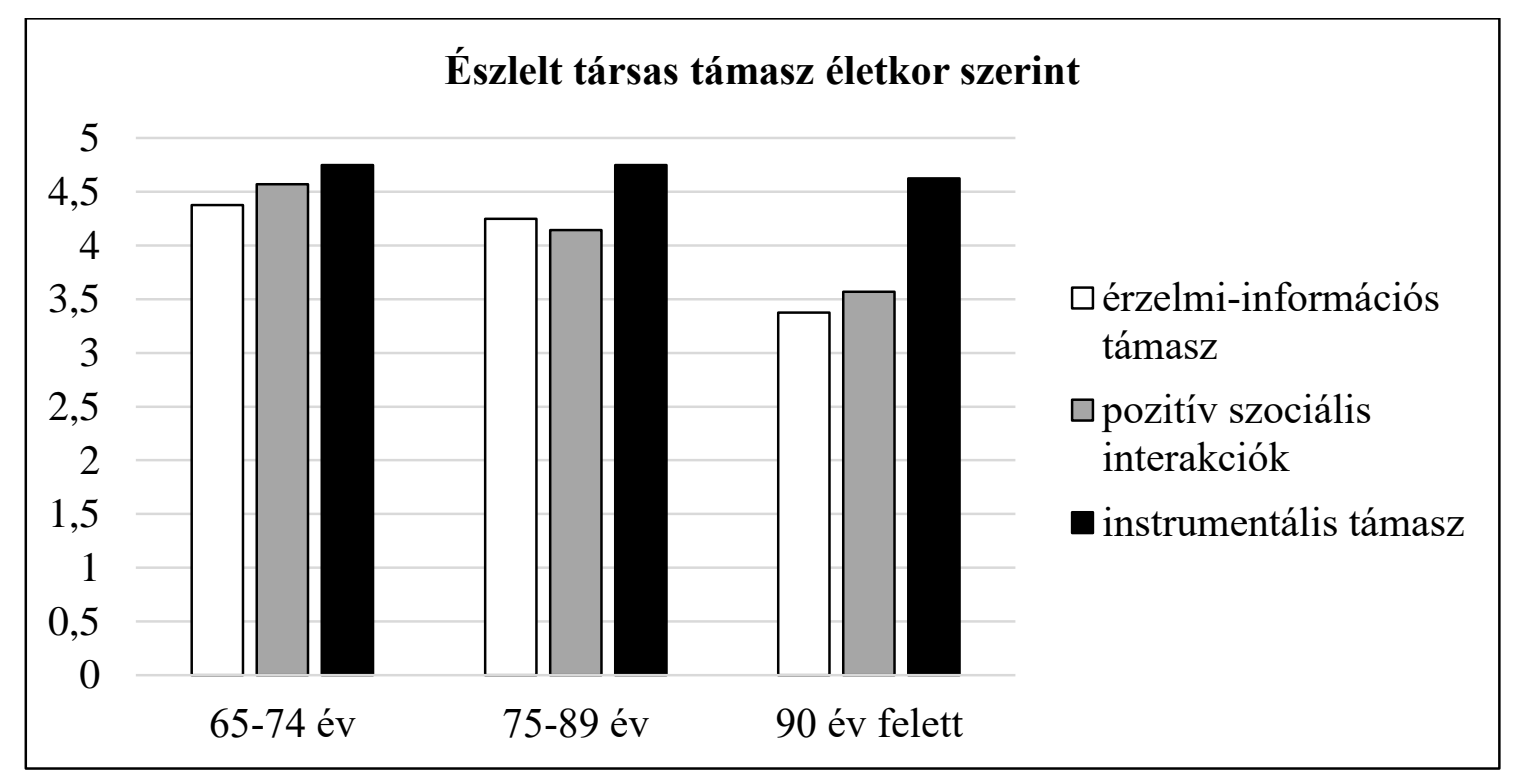

4. ábra: Észlelt társas támasz típusok összehasonlítása korcsoportonként (életkor: 65-74 év között; 75-89 év között; 90 év felett) a Társas Támasz Kérdöív 2-20. kérdéseire adott válasz alapján (lineáris modell; medián értékek) 
Az intézményesített életvitelt folytatók mindegyik támasz típus esetében szignifikánsan kisebb észlelt támaszról számoltak be, mint az önálló független életvitelt folytatók, továbbá mindkét csoport esetében az érzelmi-információs támasz kisebb mértékünek bizonyult, mint az instrumentális támasz, amely az 5. ábrán látható.

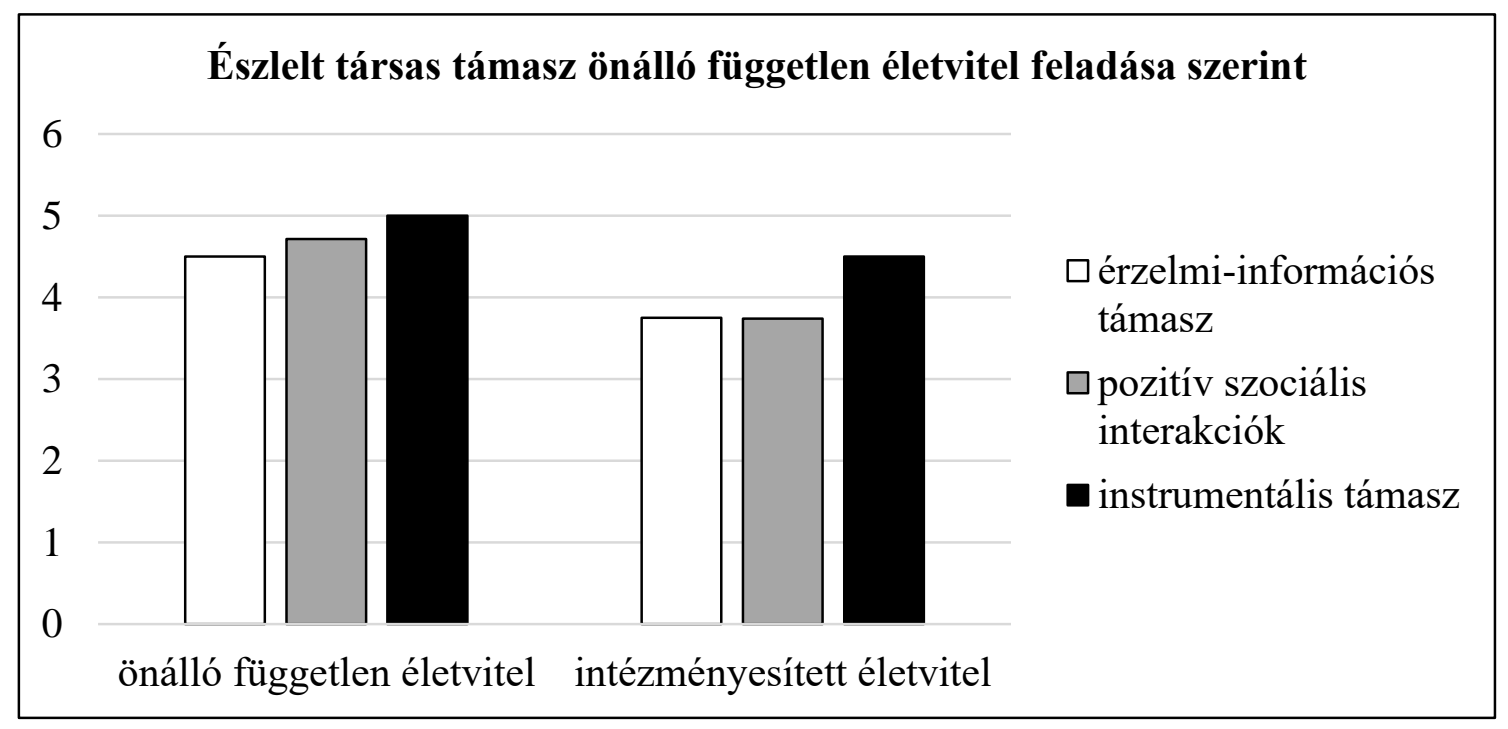

5. ábra: Észlelt társas támasz típusok összehasonlítása önálló független életvitel feladása szerint (önálló életvitelt folytatók; intézményesitett életvitelt folytatók) a Társas Támasz Kérdöiv 2-20. kérdéseire adott válasz alapján (lineáris modell; medián értékek)

A 6. ábra az önálló független életvitel feladása és az életkor változók együttes hatásának vizsgálatakor kapott eredményeket foglalja össze. Az összefoglaló árbán ugyancsak az látszik, hogy az egyes csoportok esetében az érzelmi-információs támasz bizonyult a legkisebb, míg az instrumentális támasz a legnagyobb mértékünek. 


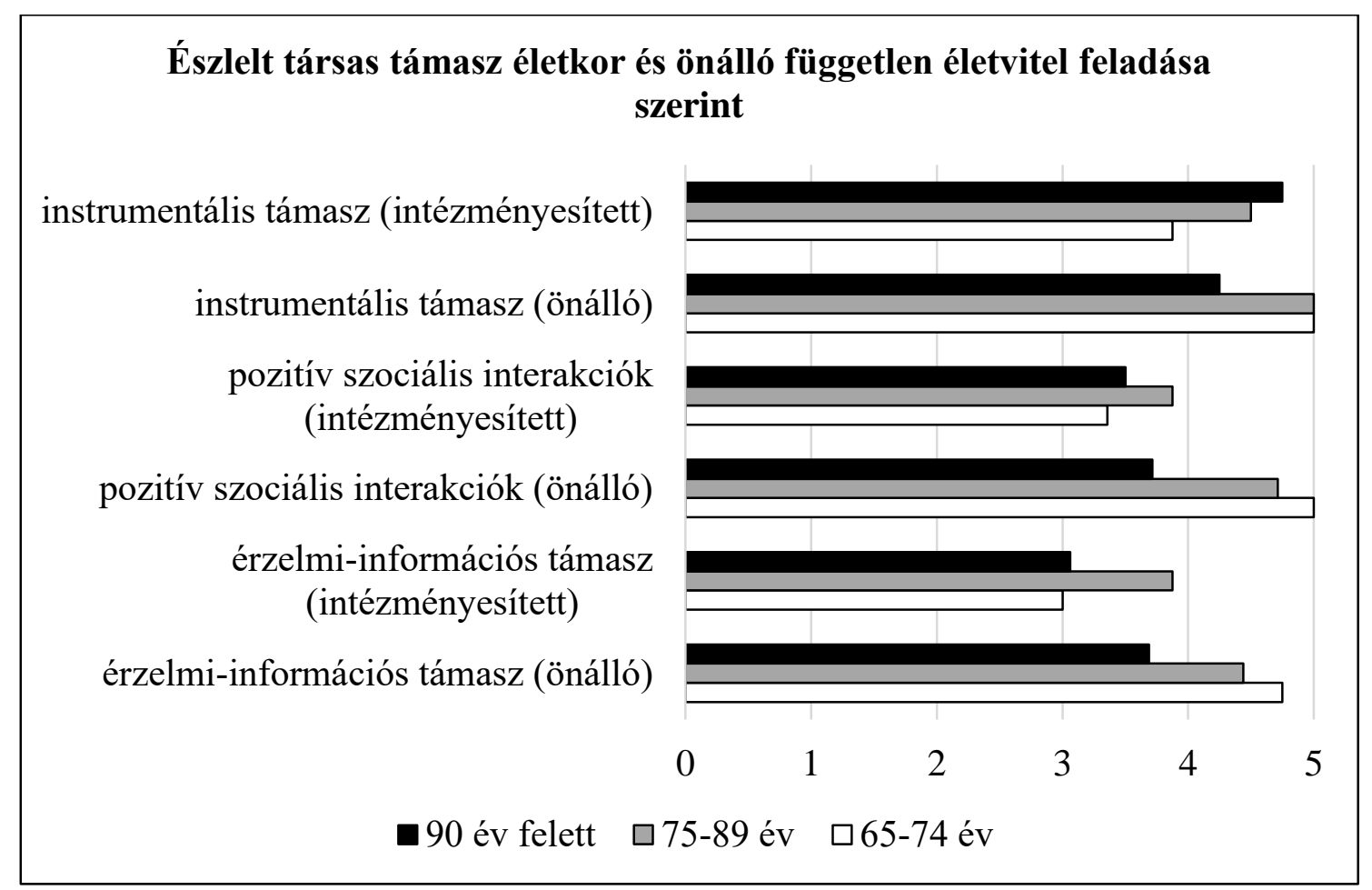

6. ábra: Észlelt társas támasz típusok összehasonlítása korcsoportonként (életkor: 65-74 év között; 75-89 év között; 90 év felett) és önálló független életvitel feladása szerint (önálló független életvitelt folytatók; intézményesített életvitelt folytatók) a Társas Támasz Kérdöiv 220. kérdéseire adott válasz alapján (lineáris modell; medián értékek)

\section{Korrelációk:}

A 6. táblázatban látható eredmények alapján jól látszik, hogy mindhárom támaszfajta közepes erősséggel (rho=0,4-0,6), vagy gyengén, de biztosan (rho=0,2-0,4) korrelál az élettel való elégedettséggel (SWLS), a támogatók számával és az idősödés növekedésként való megélésével (AAQ-növekedés) és negatívan korrelál az időskori depresszióval (GDS) és az idősödés veszteségként való megélésével (AAQ-veszteség). Vagyis minél több támogató veszi körül az időseket, annál nagyobb fokú támaszt élnek meg. Minél magasabb az észlelt támasz mértéke, annál nagyobb az élettel való elégedettség, annál kisebb mértékủ a depresszió és annál valószínübb, hogy az idősödést inkább fejlődésnek élik meg, semmint veszteségnek. Az instrumentális támasz kapcsán az utódok (gyermekek, unokák száma) és az észlelt támasz között nem volt kapcsolat, tehát ténylegesen megmutatkozik a többi családtag, barátok és hivatásos segítők szerepe időskorban. 


\begin{tabular}{|l|c|c|c|}
\hline & \multicolumn{3}{|c|}{ Támasz típusok } \\
\hline Korreláció (rho) & $\begin{array}{c}\text { Instrumentális } \\
\text { támasz }\end{array}$ & $\begin{array}{c}\text { Érzelmi- } \\
\text { információs támasz }\end{array}$ & $\begin{array}{r}\text { Pozitív szociális } \\
\text { interakciókon } \\
\text { alapuló támasz }\end{array}$ \\
\hline Támogatók száma & 0,2954 & 0,3902 & 0,5105 \\
\hline Utódok száma & nem szignifikáns & 0,2334 & 0,2528 \\
\hline SWLS & 0,4667 & 0,4121 & 0,4718 \\
\hline AAQ-növekedés & 0,3254 & 0,2636 & 0,3230 \\
\hline GDS & $-0,3301$ & $-0,3193$ & $-0,4235$ \\
\hline AAQ-veszteség & $-0,3295$ & $-0,3824$ & $-0,4563$ \\
\hline
\end{tabular}

6. táblázat: Az észlelt támasz és a vizsgálat egyes paraméterei közti korreláció (Spearmanféle rangkorreláció; rho=0,2-0,4: gyenge korreláció; rho=0,4-0,6: közepes korreláció)

\section{Következtetések és javaslatok}

Kutatásunkban azt vizsgáltuk, hogy az észlelt társas támasz mértéke milyen tényezőktől függ (nem, életkor, családi állapot, egészség, önálló független életvitel feladása), hogyan függ össze az idősödés megélésével. Kutatásunk eredménye alapján az észlelt társas támasz mértéke nem különbözik a férfiak és a nök esetében, a férfiak ugyanakkor kétszer annyi támogatóról számoltak be, mint a nők. Családi állapot tekintetében általánosságban elmondható, hogy a legkisebb észlelt támaszról és a legkevesebb támogatóról az egyedülállók és elváltak, legmagasabb észlelt támaszról és a legtöbb támogatóról a házasságban vagy élettársi kapcsolatban élők számoltak be, amely összhangban van Sz. Makó és mts. (2016) eredményeivel. Egészségi állapot tekintetében a rossz egészségi állapotban lévők kisebb támaszt észlelnek és kevesebb támogató jelenlétéről számoltak be, mint a jó, kiváló egészségi állapotúak.

Feltételezésünk szerint az észlelt társas támasz eltérö az egyes korcsoportokban, az életkor elörehaladtával csökken a társas támasz. Feltételezésünket a kutatás igazolta, mivel az egyes korcsoportok tekintetében mindhárom támaszfajta és a támogatók számának esetében is az életkorral csökkenő tendencia figyelhető meg, amely összhangban van Sz. Makó és mts. (2016) eredményeivel. Ez a közeli ismerősök, házastárs halálával bekövetkező kapcsolati háló gyengülésének, a segítő kapcsolatok csökkenésének is betudható. 
Feltételezésünk szerint az észlelt társas támasz mértéke eltérő a különböző élethelyzetekben, az intézményesitett életvitelt folytatók nagyobb mértékü támaszra számíthatnak, mint az önálló független életvitelt folytató idősek. Feltételezésünket a kutatás nagyrészt alátámasztotta. Önálló független életvitel feladása tekintetében mindhárom támaszfajta esetében szignifikáns különbség figyelhető meg az intézményesített életvitelt folytatók és az önálló életvitelt folytatók közt, az intézményesített életvitelt folytatók kisebb észlelt támaszról számoltak be mindhárom korcsoportban, mindhárom támaszfajtánál, kivéve az intézményesített életvitelt folytató 90 év felettiek esetében észlelt magasabb instrumentális támasz. Ez összhangban van Choi és mts. (2008) és Jongenelis és mts. (2004) vizsgálatainak eredményével, melyekben az idősotthonokban jelentkező depresszió egyik forrásaként a társas támasz hiányát és a nem megfelelő mennyiségű és minőségű személyzetet jelölték meg. Bár sokan épp azért költöznek idősek otthonába, hogy életük egyik leginkább kiszolgáltatott, mások segítségére utalt időszakában megfelelő támaszt kapjanak, ezen támaszt azonban inkább csak instrumentális jellegü támaszként észlelik (fizikális segítségnyújtás az étkezésben, orvosi ellátásban, stb.), nem pedig érzelmi és szociális támaszként. A támogatók száma a legfiatalabb korcsoportban tér el egymástól leginkább, míg a 90 éves kor felett ez az eltérés minimálisra csökken.

Feltételezésünk szerint az életkor és az élethelyzet együttesen hatással van az észlelt társas támasz mértékére. Feltételezésünket a kutatás alátámasztotta. Mindhárom támasz fajta esetében elmondható, hogy míg az önálló független életvitelt folytatók esetében a korral csökken az észlelt társas támasz, addig az intézményesített életvitelt folytatók esetében a legfiatalabbaknál (65-74 év) a legalacsonyabb és a 75-89 év közöttiek esetében, illetve az instrumentális támasz a legidősebbeknél a legmagasabb. A legkisebb mértékü támaszt a 65-74 év közötti, intézményesített életvitelt folytató emberek észlelik, akik túl fiatalon, többnyire hirtelen bekövetkezett állapotromlás miatt kerültek idősotthonba. Minél inkább rossz egészségben van valaki, magányos, egyedül él vagy túl korán kényszerült önálló független életvitele feladására, annál nagyobb mértékü támaszt igényelne, de úgy érzi, ezt nem kapja meg.

Magasabb észlelt társas támasz esetén nagyobb mértékủ az élettel való elégedettség, kisebb mértékü a depresszió és az idősödés megélése is pozitívabb, inkább pszichológiai növekedésként, semmint pszichoszociális veszteségként élik meg idősödésüket a válaszadók. Fontos ugyanakkor megjegyezni, hogy a ténylegesen nyújtott támasz és az észlelt támasz nem azonos. Érdemes lehet megvizsgálni azt is, hogy az idősek kiktől (pl. család, barátok, szociális segítők, stb.) milyen jellegü támaszt (pl. instrumentális, érzelmi, stb.) igényelnek és kapnak meg, illetve ebből milyen mértékü támaszt észlelnek. Az érzelmi támasz szinte minden esetben 
alacsonyabb volt, mint az instrumentális támasz, a válaszadók tehát úgy érzékelik, hogy a szükséges fizikális segítségnyújtás elérhető a számukra, ugyanakkor kevés lehetőség mutatkozik arra, hogy valaki meghallgassa öket, közös programokat szervezzen velük. Az idősotthonokban, nyugdíjas klubokban, vallási közösségekben számos programlehetőség kínálkozik, sokszor elérhető hivatásos segítő, ennek ellenére mégis érzik inkább magányosnak magukat az idősek.

Kiemelkedően fontos lenne az egyedül élő legidősebb emberek és az idősotthonokban élők érzelmi támogatása. A pandémia időszakában az idősotthonokban elrendelt látogatási tilalom és az emberi élet védelme érdekében elrendelt, az önellátásra képes időseket is érintő egyéb korlátozások ugyanakkor tovább csökkenthetik az érzelmi és a pozitív szociális interakciókon alapuló észlelt társas támaszt és az érzelmi támaszt, amelyek minden korcsoportban és élethelyzetben eleve alacsonyabbnak bizonyultak, mint az instrumentális támasz. 


\section{Irodalomjegyzék}

Bácskay A. (2017): Területi különbségek az idősgondozásban. In: Ezüstkor: korosodás és társadalom. KSH, 28-34.

Bácskay A., Balogh K., Gregorits P., Kovács B., Mura-Mészáros P., Németh M., Pintér Á., Szabó R. (szerk.): Szociális statisztikai évkönyv, 2016. KSH, 2017

Boga B. (szerk., 2015): Idősgondozási kézikönyv. - A magyarországi idősotthonok és hospiceok adatbázisával. Geriáter Service Kiadó.

Boros J. (2017): Egészség időskorban. In: Ezüstkor: korosodás és társadalom. KSH, 35-50.

Choi, N. G., Ransom, S., \& Wyllie, R. J. (2008): Depression in older nursing home residents: The influence of nursing home environmental stressors, coping, and acceptance of group and individual therapy. Aging \& Mental Health, 12(5), 536-547.

Forgács A. (2015): Társas támasz a gyászban. In: Kiss E. Cs., Sz. Makó H. (szerk.): Gyász, krízis, trauma és a megküzdés lélektana. Pro Pannonia Kiadó, Pécs. 382-398.

Gilour H. (2012): Social participation and the health and well-being of Canadian seniors. Component of Statistics Canada Catalogue no. 82-003-X, Health Reports. Letöltés: 2019.03.26.

Ibrahim, N., Din, N.C., Ahmad, M., Ghazali, S.E., Said, Z., Shahar, S., Ghazali, A.R. and Razali, R. (2013): Relationships between social support and depression, and quality of life of the elderly in a rural community in Malaysia. Asia-Pacific Psychiatry, 5: 59-66.

Jongenelis K., Pot A.M., Eisses H., Beekman A.T.F., Kluiter H., Ribbe M.W. (2004): Prevalence and risk indicators of depression in elderly nursing home patients: the AGED study. Journal of Affective Disorders, Volume 83, Issues 2-3, 135-142.

Kai-Kuen Leung, Ching-Yu Chen, Bee-Horng Lue, Shih-Tien Hsu (2007): Social support and family functioning on psychological symptoms in elderly Chinese. Archives of Gerontology and Geriatrics, Volume 44, Issue 2, March-April 2007, Pages 203-213.

Kállai J. (2007): Egészség és társas támogatás. In: Kállai J., Varga J., Oláh A. (szerk.): Egészségpszichológia a gyakorlatban. Medicina Könyvkiadó, 199-214.

Kopp M., Székely A. (2013): Nagyszülők, szülők és unokák: testi és lelki egészség. A generációk közötti kapcsolatok egészségpszichológiai szerepe. In: Kállai J., Kaszás B, Tiringer I. (szerk.): Az időskorúak egészségpszichológiája. Medicina Kiadó, Budapest. 105-118.

Lampek K., Rétsági E. (2015): Egészséges idősödés - az egészségfejlesztés lehetőségei időskorban. Pécsi Tudományegyetem Egészségtudományi Kar 
Martos T., Désfalvi J., Ittzés A., Sallay V., Szabó T. (2014): Az Élettel való Elégedettség Skála magyar változatának (SWLS-H) pszichometriai jellemzői. Mentálhigiéné és Pszichoszomatika 15 (2014) 3, 289-303.

Monostori J., Gresits G. (2018): Idősödés. In: Demográfiai portré 2018. Jelentés a magyar népesség helyzetéről. KSH Népességtudományi Kutatóintézet. 127-145.

Morley, J. E. (2010). Depression in Nursing Home Residents. Journal of the American Medical Directors Association, 11(5), 301-303.

Osváth P., Árkovits A., Csürke J. (2014): A „korfüggő krízisek” - az életközepi és az időskori krízis. In: Csürke J., Vörös V., Osváth P., Árkovits A. (szerk): Mindennapi kríziseink - A lélektani krízis és a krízisintervenció kézikönyve. Oriold és Társai Kiadó, Budapest. 187203.

Pék Gy. (2007): Egészségpszichológiai szempontok időskorban. In: Kállai J., Varga J., Oláh A. (szerk.): Egészségpszichológia a gyakorlatban. Medicina Könyvkiadó, 469-491.

Székely G. (2017): Lakáspiaci életutak. In: Ezüstkor: korosodás és társadalom. KSH, 18-27.

Sz. Makó H., Bernáth L., Szentiványi-Makó N., Veszprémi B., Vajda D., Kiss E. Cs. (2016): A MOS SSS - Társas Támasz mérésére szolgáló kérdőív magyar változatának pszichometriai jellemzői. Alkalmazott Pszichológia, 2016, 16(3):145-162.

Tiringer I., Kaszás B. (2013): Az időskor pszichológiai jellemzői. In: Kiss E. Cc., Sz. Makó H. (szerk.): Mentálhigiéné és segitö hivatás. Pro Pannonia Kiadó, Pécs. 53-66.

Tróznai T., Kullmann L. (2007): Az idős emberek életminőségének és idősödéssel kapcsolatos attitüdjeinek vizsgálata. LAM 2007;17(2):137-143.

Unalana D., Gocerb S., Basturkc M., Baydurd H., Ozturke A. (2015): Coincidence of low social support and high depressive score on quality of life in elderly. European Geriatric Medicine, Volume 6, Issue 4, July 2015, Pages 319-324.

\section{A szerzők:}

\section{Ferwagner Anna}

ferwagner.anna@gmail.com

\section{Dr. Pék Győző PhD}

Debreceni Egyetem, Pszichológiai Intézet

4032 Debrecen, Egyetem tér 1.

viktorbaker55@gmail.com 


\section{Levelező szerző:}

\section{Ferwagner Anna}

PhD hallgató, Debreceni Egyetem Humán Tudományok Doktori Iskola Pszichológia Program e-mail: ferwagner.anna@gmail.com 